DOI: https://doi.org/10.34069/AI/2021.43.07.15

How to Cite:

Kirikova, E., \& Kelchevskaya, N. (2021). Energy conservation culture and energy performance of industrial companies. Amazonia Investiga, 10(43), 150-157. https://doi.org/10.34069/AI/2021.43.07.15

\title{
Energy conservation culture and energy performance of industrial companies
}

\section{Культура энергосбережения и энергетическая результативность промышленных компаний}

Received: June 3, 2021

(J) 3,2021

Accepted: August 5, 2021

\author{
Written by: \\ Elena Kirikova ${ }^{55}$ \\ https://orcid.org/0000-0002-0414-8139 \\ Natalia Kelchevskaya $^{56}$ \\ https://orcid.org/0000-0001-7278-026X
}

\begin{abstract}
Recent years have seen sparked interest to business models based on sustainable development, which seek harmonious codevelopment of human resources, organizational culture, and production systems. This paper analyzes how HR management practices, a culture of energy conservation, and staff's knowledge regarding energy efficiency affect the ability of Russian industrial companies to reach their targets in energy management. Methods in use involve factor analysis, structural equation modeling (SEM), and the author-developed questionnaire that is designed to measure the effects of internal intellectual factors (human resources, culture, and knowledge) on industrial energy performance. For the first time, this paper presents an SEM-based estimation of HR practices and their effects on industrial energy performance. Empirically, this study is based on the results of surveys that involved managers and technical officers of 14 Russian industrial companies in 2016-2017. Analysis shows that employee training, development of energy efficiency skills, and sharing knowledge on energy conservation issues do contribute to reaching the energy policy targets.
\end{abstract}

\section{Аннотация}

Keywords: energy management, energy performance, human resources, energy conservation culture.

В последние годы возник интерес к бизнесмоделям, основанным на устойчивом развитии, которые стремятся к гармоничному совместному развитию человеческих ресурсов, организационной культуры и производственных систем. В данной статье анализируется, как методы управления персоналом, культура энергосбережения и знания сотрудников в области энергоэффективности влияют на способность российских промышленных компаний достигать своих целей в области управления энергопотреблением. Используемые методы включают факторный анализ, моделирование структурным уравнением (SEM) и разработанный автором вопросник, предназначенный для измерения влияния внутренних интеллектуальных факторов (человеческие ресурсы, культура и знания) на энергетические показатели промышленности. В данной статье впервые представлена оценка практики управления персоналом и их влияния на энергетические показатели промышленности на основе SEM. Эмпирически данное исследование основано на результатах опросов руководителей и технических специалистов 14 российских промышленных компаний в 20162017 гг. Анализ показывает, что обучение сотрудников, развитие навыков энергоэффективности и обмен знаниями по вопросам энергосбережения действительно способствуют достижению целей энергетической политики.

Ключевые слова: энергетический менеджмент, энергетическая результативность, человеческие ресурсы, культура энергосбережения.

\footnotetext{
55 Associate Professor, Institute of Economics and Management, Ural Federal University, Ekaterinburg, Russia.

${ }^{56}$ Professor, Institute of Economics and Management, Ural Federal University, Ekaterinburg, Russia.
} 


\section{Introduction}

In the context of globalization, countries, regions, and companies of different sizes focus on controlling their increasing energy consumption and improving the energy efficiency of production activities. Global crises such as the 1970s energy crisis coupled with the environmental disasters of today urged developed countries to rationalize energy conservation efforts in an approach based on systematicity, long-term planning, responsible use and development of the environment. Macroeconomic energy management is also facing challenges of the strife for better environmental performance in developing countries as indicated by the reduction in greenhouse gas emissions. A comprehensive solution lies not only in adapting ISO 50001 (Kodeks, 2012), an international energy management standard, but also in making further use of smart management technologies that combine best managerial practices and progressive HR management.

Industrial consumption of energy accounts for $31 \%$ of the total primary energy sources and produces $36 \%$ of the total global emissions of carbon dioxide (International Energy Agency, 2007). As energy prices continue to rise, and countries/regions that host industrial facilities adopt stricter environmental laws whilst consumer trust shifts towards 'green tech', energy conservation becomes an ever more pressing issue (Bunse et al, 2011). Empirical studies have shown that in the coming years, systemic energy management can help industrial enterprises cut their energy consumption by up to 40\% (Ates and Durakbasa, 2012). These principles are based on adopting energy management elements in all departments; these elements include better organizational culture and advanced HR management practices. This paper explores how the organizational culture of energy conservation and HR management practices contribute to the better energy and environmental performance of industrial facilities. The empirical study based on structural equation modeling tests hypotheses made as part of the general model that shows the relationships between management practices and performance indicators.

\section{Literature Review}

This study primarily addresses issues of human resource management and organizational culture as part of industrial energy management. This section defines each of the theoretical constructs that will be used in further modeling. They include energy performance, organizational culture and the resulting culture of energy conservation, as well as HR management practices. Earlier studies have shown that an organizational culture that promotes energy performance is, along with HR practices, a crucial variable of the in-house environment that defines the strategic prospects of the company's development. By testing this hypothesis on the empirical data of Russian companies, we will be able to make a series of practical recommendations on better energy management strategies.

Energy Performance. Energy performance per ISO 50001 refers to 'measurable results regarding energy efficiency, use, and consumption' (Kodeks, 2012). Thus, energy performance consists in the ability to attain the operational and strategic organizational goals with respect to energy management. Energy performance has several indicators that the company/city/region/country chooses to best suit its activities (Augenbroe et al, 2009). Such indicators may include energy efficiency indicators and other socioeconomic, organizational, and production indicators depending on the type of the actor (Teixeira et al, 2016; Li et al, 2016). Energy performance must contribute to the company's sustainable development and overall performance (Vikhorev et al, 2012). The overall performance of a forprofit organization can boil down to increase in sales, profitability, or change in the market share (Andreeva and Garanina, 2016). Thus:

H1: the energy performance of a company has a significant correlation with the overall performance as measured by increase in sales, profitability, and market share.

Organizational Culture. Organizational culture incorporates values that emphasize novelty and innovation as well as those that focus on costeffectiveness. Each element of the culture has a strategic foundation (Hock et al, 2016). Schulze et al (2016) list education/training, motivation, and internal communications as elements of organizational culture in energy management. This paper further uses the term 'energy conservation culture' or 'culture of energy conservation' to denote a specific component of organizational culture that pertains to the principles of energy management. These are employee-embraced internal values and expectations pertaining to the development and 
adoption of energy management for systematic improvement in energy performance. Energy conservation culture is in any case a complex matter that stems from the internal goals of energy management and understanding its management principles on all levels; a systematic approach to energy conservation is a sign of advanced culture.

Schulze et al (2016), based on a very extensive study of the topic, reduce cultural management issues to learning, motivation, and establishing internal relationships. Energy-intensive industries in France (oil refining, metallurgy, transport, etc.) are another example of why responsibilities and duties relating to HR must be clearly split and referred within the organization (Lesourd and Ruiz, 1984). Top managers are tasked to devise an energy consumption strategy, to coordinate investment, to maintain and advance their cooperation with public agencies that control the area and with the local community. Specialized education and training, including continuous education, is the vehicle of the principles of energy-efficient production (Lesourd and Ruiz, 1984). Thus, culture is important for high performance in production, which leads as to the following hypotheses:

$\mathrm{H} 2$ : there is a significant correlation between the culture of energy conservation and the energy performance.

$\mathrm{H} 3$ : there is a significant correlation between the culture of energy conservation and the overall performance of the organization.

HR management practices encompass a whole range of applied technologies that are systematically used in scheduling, organizing, monitoring, and motivating staff for the company to operate more efficiently. Theoretically, HR management practices constitute a vehicle that carries the culture of energy conservation to all levels. Previous empirical studies suggest a varying degree of how HR management practices influence the energy and environmental performance. Thus, Ulubeyli (2013) cites cement factories in Turkey to show lack of correlation between HR strategies, energy strategies, and environmental performance. On the other hand, Liu et al (2012) discuss industrial facilities in China to reveal a correlation between the intensity of in-house training and the company's rate of adopting energy conservation measures. However, the researcher does not find a significant correlation between the latter and the employees' preexisting education or knowledge of energy management programs. Based on the foregoing studies, we formulate the following hypotheses for testing:

$\mathrm{H} 4$ : there is a significant correlation between HR management practices and the energy performance.

H5: there is a significant correlation between HR management practices and the overall performance of an organization.

Smart management technologies that combine the concepts of energy conservation culture and HR management practices do contribute to maintaining the performance. Consistent innovation might fuel smarter management. Jacobs (2012) investigates the case of ExxonMobil, a transnational corporation, and note that persistent innovation and cooperation of stakeholders may improve energy performance. The author believes leadership, training, and exceptional abilities to be the key factors that stimulate innovation. The company organizes intensive training for its employees and students (interns); it also implements a consistent R\&D policy. Bunse et al (2011) analyzed the gap between what industrial energy management needs and what technology could offer today; they thus stated the key focus areas for the development of energy systems. The focus should first and foremost be made on adopting processes based on knowledge and information management in monitoring and controlling internal energy consumption. Christoffersen et al (2006) studied the case of Danish companies to show that the knowledge of energy management is fundamental to the practical adoption of energy conservation practices. Such 'smartening' of management also requires training and education management, a motivation system in place to have more and better initiatives in energy management, and analysis of the delegation of responsibility in the context of energy conservation.

Russian researchers Okorokov et al (2010) note that in a smart economy, energy system management places a strong emphasis on the psychological component, i.e., on the speed and quality of decision-making. Kondratieva and Pogrebnjak (2014) also note the importance of internal socioeconomic factors in the energy management system, from management ideology and agenda to individualized approach to uplifting each employee. In light of the reviewed smart management studies, we draw the following hypothesis:

H6: there is a significant correlation between the knowledge of energy conservation and energy performance. Figure 1 shows the general model for empirical testing of the hypotheses. 


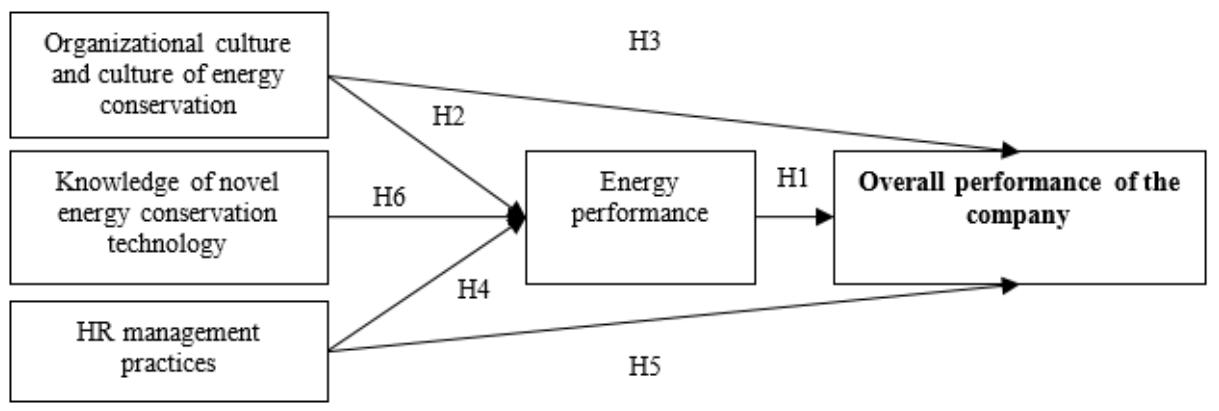

Figure 1. General theoretical model of how culture, HR management practices, and knowledge of novel energy conservation technologies correlate with the company's energy performance and overall performance. Source: author's source

\section{Methodology}

The hypotheses made above are tested by structural equation modeling. Today's management studies use structural equation modeling (SEM) as one of the most effective methods for quantitative investigation of implicit theoretical constructs and for testing theories against business practices. SEM combines confirmatory factor analysis and regression analysis; this combination has multiple research applications (Babin and Svensson, 2012). Today's research in management often relies on SEM to test hypotheses and theoretical constructs. SEM normally uses a set of items to reflect an implicit construct that in turn reflects the specific perception of this or that problem or phenomenon as well as the behavioral aspects of actors in management as they manifest in a variety of situations.

Variables for Modeling. To formulate the explicit variables (items) of overall performance, we used

Table 1.

Core variables involved in SEM factor analysis. such metrics as total increase in sales, profitability, and market share (Andreeva, and Garanina, 2016). Each of the items was subjectively evaluated by the respondents on a Likert scale from 1 (totally disagree) to 7 (totally agree). At this point and thereafter, we asked energy management officers to subjectively answer such question as, "Do you agree that your Company has been more successful than its competitors in terms of sales revenue growth?" etc. To estimate energy performance, we used several variables from previous studies; survey questions were based on energy strategy implementation studies (Ulubeyli, 2013) and the international standard (Kodeks, 2012). Questions concerning organizational culture, energy conservation culture, and education/training practices were adapted from (Liu et al, 2012), whereas questions regarding knowledge of energy and environmental management, as well as that of alternative energy sources, were adapted from (Lin and Syrgabayeva, 2016).

\begin{tabular}{|c|c|c|}
\hline Factor & $\begin{array}{l}\text { Code of variable within the } \\
\text { factor }\end{array}$ & Corresponding Likert-scale question \\
\hline \multirow{7}{*}{ 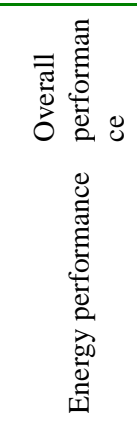 } & PERF_12_1 & $\begin{array}{l}\text { The Company has been more successful than its competitors in terms of } \\
\text { sales revenue growth }\end{array}$ \\
\hline & PERF_12_2 & The Company has been successful in terms of increase in profitability \\
\hline & PERF_12_3 & The Company has been successful in terms of increase in market share \\
\hline & EN_PERF_9_1 & $\begin{array}{l}\text { The Company plans and adopts energy conservation measures on a } \\
\text { regular basis }\end{array}$ \\
\hline & EN_PERF_9_2 & $\begin{array}{l}\text { In general, we keep effectively reducing the energy costs per unit of } \\
\text { product }\end{array}$ \\
\hline & EN_PERF_9_3 & $\begin{array}{l}\text { The Company effectively reuses (recycles) energy; irretrievable energy } \\
\text { losses show decline }\end{array}$ \\
\hline & EN_PERF_9_4 & $\begin{array}{l}\text { The Company audits its energy consumption on a regular basis; the } \\
\text { energy management system is subject to continuous improvement }\end{array}$ \\
\hline & EN_CULT_10_1 & Every employee of the Company is aware of energy efficiency issues \\
\hline \multirow{3}{*}{ 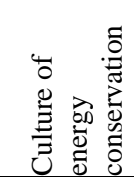 } & EN_CULT_10_2 & $\begin{array}{l}\text { The Company's employees are always ready to partake in effort to } \\
\text { improve energy efficiency }\end{array}$ \\
\hline & EN_CULT_10_3 & $\begin{array}{l}\text { Top managers are aware of the importance of energy conservation and } \\
\text { support energy conservation initiatives }\end{array}$ \\
\hline & EN_CULT_10_4 & All staff involved in production is highly qualified in energy conservation \\
\hline
\end{tabular}

Source: author's source 
Data was collected by targeted surveying by means of Google Forms in 2016 and 2017. The questionnaire had five blocks of statements and questions relating to the factors in Table 1 and to monitored data (industry, size of the company, respondents' age and positions). Each statement corresponded to one variable to be further encoded and combined into factors. Over the course of the study, we surveyed 178 people from 14 industrial and construction companies: $52.8 \%$ from steelmaking companies, $16.9 \%$ from mechanical engineering companies, $15.7 \%$ from extractive firms, the rest from energy distribution and from the construction sector. The surveys mainly targeted energy management officers including low-level and middle managers $(34.8 \%)$ and engineers (53.9\%), mostly aged 26 to $45(86.5 \%)$.

\section{Results and Discussion}

The first step of modeling was to estimate the consistency of intra-factor variables by Cronbach's alpha, and to run factor analysis in order to assess the factor loading for each item (see Table 2). Bartlett's sphericity test proved this factor analysis adequate.

Table 2.

Results of factor analysis.

\begin{tabular}{|c|c|c|c|c|c|}
\hline Factor & Variable code & Mean value & Std. Dev. & $\begin{array}{l}\text { Cronbach's } \\
\text { alpha }\end{array}$ & $\begin{array}{l}\text { Factor } \\
\text { loading }\end{array}$ \\
\hline \multirow{4}{*}{$\begin{array}{l}\text { Culture of energy } \\
\text { conservation }\end{array}$} & EN_CULT_10_2 & 3.09 & 0.125 & \multirow{4}{*}{0.794} & 0.857 \\
\hline & EN_CULT_10_4 & 3.37 & 0.123 & & 0.808 \\
\hline & EN_CULT_10_3 & 4.53 & 0.124 & & 0.587 \\
\hline & EN_CULT_10_1 & 3.16 & 0.121 & & 0.571 \\
\hline \multirow{6}{*}{ HR practices } & HRM_PR_11_4 & 3.27 & 0.120 & \multirow{6}{*}{0.893} & 0.834 \\
\hline & HRM_PR_11_5 & 3.00 & 0.135 & & 0.826 \\
\hline & HRM_PR_11_3 & 2.91 & 0.123 & & 0.802 \\
\hline & HRM_PR_11_1 & 2.88 & 0.117 & & 0.627 \\
\hline & HRM_PR_11_2 & 2.65 & 0.116 & & 0.579 \\
\hline & HRM_PR_11_6 & 2.88 & 0.130 & & 0.550 \\
\hline \multirow{4}{*}{$\begin{array}{l}\text { Energy } \\
\text { performance }\end{array}$} & EN_PERF_9_1 & 4.53 & 0.123 & \multirow{4}{*}{0.888} & 0.857 \\
\hline & EN_PERF_9_2 & 4.10 & 0.129 & & 0.772 \\
\hline & EN_PERF_9_3 & 3.39 & 0.122 & & 0.732 \\
\hline & EN_PERF_9_4 & 3.66 & 0.131 & & 0.635 \\
\hline \multirow{3}{*}{ Performance } & PERF_12_2 & 3.90 & 0.132 & \multirow{3}{*}{0.959} & 0.930 \\
\hline & PERF_12_3 & 3.97 & 0.132 & & 0.909 \\
\hline & PERF_12_1 & 4.19 & 0.137 & & 0.892 \\
\hline \multirow{3}{*}{$\begin{array}{l}\text { Knowledge of } \\
\text { energy } \\
\text { conservation }\end{array}$} & EN_KNOW_13_2 & 4.31 & 0.141 & \multirow{3}{*}{0.887} & 0.881 \\
\hline & EN_KNOW_13_3 & 4.53 & 0.130 & & 0.852 \\
\hline & EN_KNOW_13_1 & 3.80 & 0.148 & & 0.852 \\
\hline
\end{tabular}

Source: author's source

Factor analysis based on principal component analysis and varimax rotation with Kaiser normalization showed the empirical material to lack variables with a factor loading below 0.5 ; Cronbach's alpha was good ( $>0.8$ stands for good consistency), a sign of the theoretical constructs in question being reliable. Thus, all the proposed variables were suitable for further modeling. Factor loading analysis highlighted the importance of employees' willingness to partake in energy management initiatives; their applicable technical qualifications and skills were of significance, too. The work of energy management teams and the in-house sharing of energy conservation knowledge are critical for HR management practices. Despite that, the variables consistently averaged below 4 , which could be roughly equated to a neutral attitude to the statement given in the questionnaire; this did not apply to the metrics of energy performance and energy conservation knowledge. As for the knowledge of energy conservation, high factor loading was characteristic of the knowledge of key energy management methods applicable to the respondent's job; same applies to the knowledge of renewable energy sources.

We further ran Amos, an SPSS extension, to plot a path diagram shown in Figure 2, for which we calculated standardized coefficients, paired variable-factor regression coefficients, and model quality metrics (GFI, AGFI, etc.). 


\section{AMAZONIA \\ 1nvestiga}

Analysis of the resulting structural model showed HR management practices (b (nonstandardized regression coefficient $)=0.764, \mathrm{t}=$ 3.557, significant at $\mathrm{p}<0.01$ ), and energy conservation knowledge $(b=0.266, t=3.156$, significant at $\mathrm{p}<0.01)$ to have the strongest impact on energy performance. On the contrary, overall culture of energy conservation as measured by staff involvement in energy conservation and their commitment to the values of energy management did not affect energy performance significantly; however, culture was found to contribute significant to the company's overall performance. Correlation analysis revealed strong correlation between the factor of energy conservation culture and HR management practices (coefficient of 0.93).

Model quality (fit) indicated acceptable significance of the results. CMIN / DF (chisquare statistic by number of degrees of freedom) $=1.713$, GFI (goodness to fit index) $=0.864$, AGFI (adjusted GFI) $=0.834$ (acceptable fit), RMSEA (root mean square error of approximation $)=0.007$ at PCLOSE $=0.005$ (good fit) (Nasledov, 2013). Table 2 shows hypothesis test results.

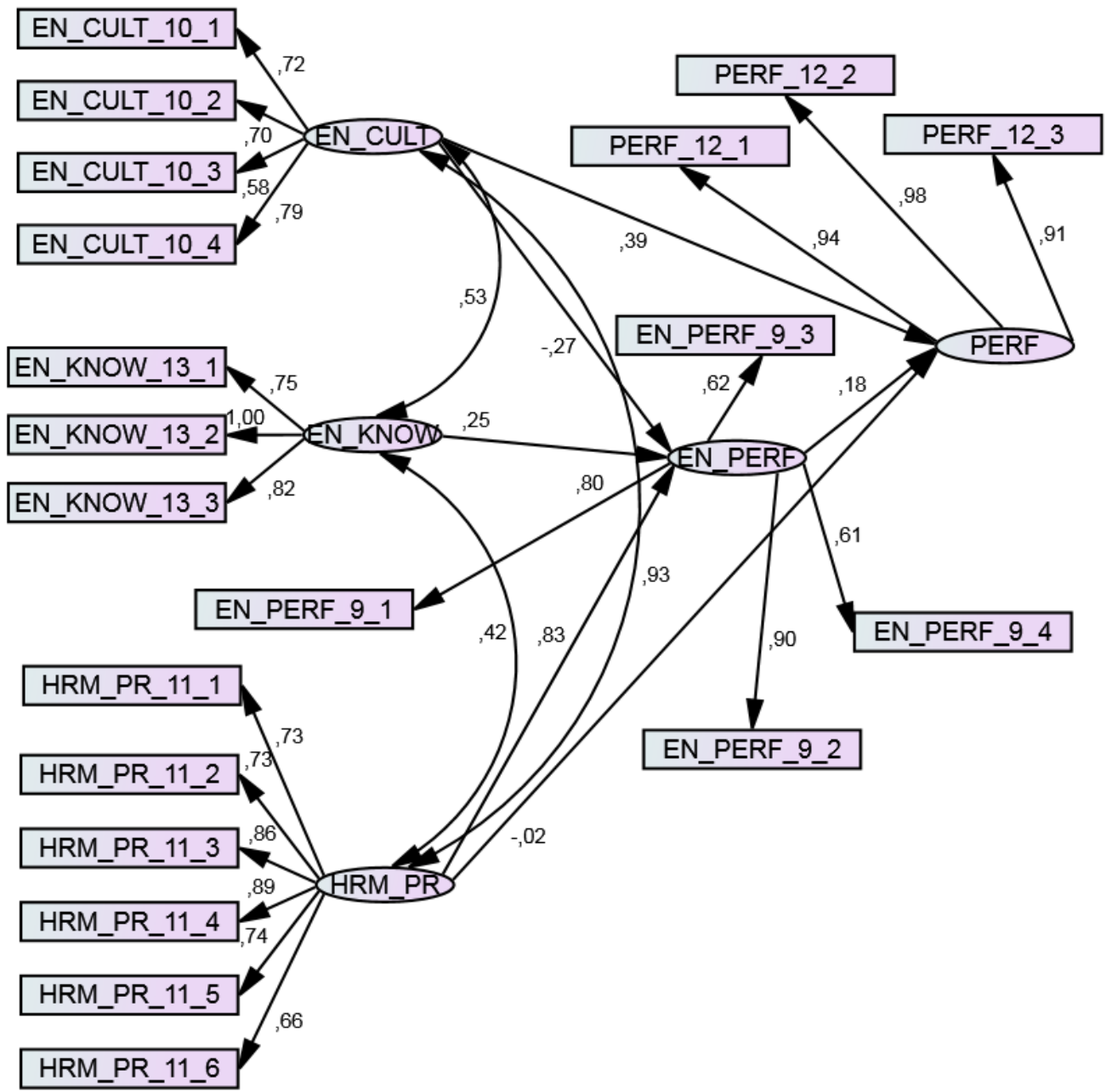

Figure 2. Path diagram with standardized coefficients (ovals for factors, rectangles for items, doublearrowed lines for factor covariation, single-arrowed lines for the direction of relation, all coefficients standardized and therefore cross-comparable. Source: author's source 
Table 3.

Hypothesis test results.

\begin{tabular}{|c|c|}
\hline Hypothesis & Test results \\
\hline H1 & $\begin{array}{l}\text { Rejected. Contrary to expectations, the energy performance and the overall performance of a } \\
\text { company have not been found to correlate significantly. It might be the case that technical } \\
\text { officers and managers enrolled in this study lack understanding of energy conservation } \\
\text { management, and the related issues were not a focus of strategic planning. Besides, the overall } \\
\text { performance of a company depends to a greater extent on the market and political factors on a } \\
\text { global scale; since many steelmaking and oil-and-gas companies are export-oriented, } \\
\text { international factors do compromise their competitiveness, e.g., sanctions against steelmakers or } \\
\text { falling oil prices. Meanwhile, whilst revenue in a foreign currency technically increases in ruble } \\
\text { terms, this increase does not contribute sufficiently to how officers perceive their companies' } \\
\text { performance. }\end{array}$ \\
\hline H2 & $\begin{array}{l}\text { Rejected. Organizational culture and energy performance have not been found to correlate } \\
\text { significantly. This might be due to weak involvement of low-tier staff in energy conservation } \\
\text { efforts as well as their poor commitment to the values of energy management. In the context of } \\
\text { Russian industrial companies, such factors are associated with effective energy management only } \\
\text { on paper, whilst practical skills of staff were given emphasis. }\end{array}$ \\
\hline $\mathrm{H} 3$ & $\begin{array}{l}\text { Confirmed. The culture of energy conservation is indeed associated with a better overall } \\
\text { performance; key role in this process is played by top managers' awareness of energy } \\
\text { conservation issues and their support for energy conservation initiatives. }\end{array}$ \\
\hline $\mathrm{H} 4$ & $\begin{array}{l}\text { Confirmed. HR management practices do affect energy performance, with effective sharing of } \\
\text { energy management knowledge and the emphasis on energy management skills in recruitment } \\
\text { being the key practices. }\end{array}$ \\
\hline H5 & $\begin{array}{l}\text { Rejected. No significant stable correlation found between HR management practices and the } \\
\text { company's overall performance. Importantly, the results on this hypothesis are also affected by } \\
\text { market factors; besides, when compared to other internal components of industrial companies' } \\
\text { competitiveness, energy management may remain insignificant, as energy costs usually only } \\
\text { account for } 5 \% \text { to } 9 \% \text { of production costs (figure applies to surveyed companies). }\end{array}$ \\
\hline & $\begin{array}{l}\text { Confirmed. Significant stable correlation found between knowledge of energy-efficient } \\
\text { technologies and the company's energy performance, as had been theorized. Knowledge of the }\end{array}$ \\
\hline H6 & key principles and provisions of the Energy Management Systems standard coupled with \\
\hline & $\begin{array}{l}\text { knowledge of renewable energy and industry-specific energy-efficient techniques help reach the } \\
\text { energy policy targets. }\end{array}$ \\
\hline
\end{tabular}

Source: author's source

\section{Conclusions}

This paper uses factor analysis and structural equation modeling to investigate how individual internal variables of an industrial company affect its energy and overall performance. It analyzes data on 14 Russian industrial and construction companies. Focus is made on such theoretical constructs as the culture of energy conservation, HR management practices, and employees' knowledge of energy conservation. Analysis shows HR management practices (training and education, workshops and meetings on energy management, and human capital development planning) to contribute significantly to the energy performance of Russian industrial companies. Companies that undertake to advance the knowledge and skills of their employees with regard to energy management, companies that apply the principles of the internal standard are indeed capable of effectively cutting the costs per unit of product and to maintain internal processes for ever better energy management. Contrary to the hypothesis, the values of energy conservation do not have a significant practical impact on energy performance; however, they somewhat affect the company's overall international competitiveness.

Further research could revolve around the analysis of how HR management factors affect the company's energy performance in the context of energy managers' commitment to adopting improvements and innovation in energy efficiency management. This paper also gives no consideration to environmental performance, which, along with energy management practices, contributes significantly to overall performance of companies based in developed countries, as the latter tend to stringently control the environmental and energy performance of businesses. Russian companies might as well soon face the need to train their employees if they are to remain competitive.

\section{Bibliographic references}

Andreeva, T., \& Garanina, T. (2016). Do all elements of intellectual capital matter for organizational performance? Evidence from 


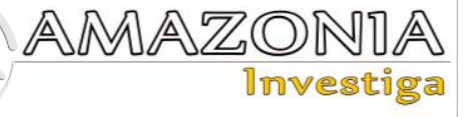

Russian context. Journal of Intellectual Capital, 17(2), 397-412. https://doi.org/10.1108/JIC-072015-0062

Ates, S.A., \& Durakbasa, N.M. (2012). Evaluation of corporate energy management practices of energy intensive industries in Turkey. Energy, 45(1), 81-91. https://doi.org/10.1016/j.energy.2012.03.032 Augenbroe, G., Castro, D., \& Ramkrishnan, K. (2009). Decision model for energy performance improvements in existing buildings. Journal of Engineering, Design and Technology, 7 (1), 21-36.

https://doi.org/10.1108/17260530910947240

Babin, B.J., \& Svensson, G. (2012). Structural equation modeling in social science research. European Business Review, 24(4), 320-330. https://doi.org/10.1108/09555341211242132

Bunse, K., Vodicka, M., Schönsleben, P., Brülhart, M., \& Ernst, F.O. (2011). Integrating energy efficiency performance in production management - gap analysis between industrial needs and scientific literature. Journal of Cleaner Production, 19(6-7), 667-679. https://doi.org/10.1016/j.jclepro.2010.11.011 Christoffersen, L.B., Larsen, A., \& Togeby, M. (2006). Empirical analysis of energy management in Danish industry. Journal of Cleaner Production, 14(5), 516-526. https://doi.org/10.1016/j.jclepro.2005.03.017

Hock, M., Clauss, T., \& Schulz, E. (2016). The impact of organizational culture on a firm's capability to innovate the business model. R\&D Management, 46(3), 433-450. https://doi.org/10.1111/radm.12153

International Energy Agency (2007). Tracking Industrial Energy Efficiency and $\mathrm{CO} 2$ Emissions. Paris, France: IEA Publications.

Jacobs, E.F. (2012). IRI Medal: Meeting Tomorrow's Energy Demand through Innovation and Collaboration. Research-Technology Management, 55 (6), 25-31. Retrieved June 23, 2021, from https://www.jstor.org/stable/26586646

Kodeks, JSC (2012). Standard GOST R ISO 50001-2012. System energy management: requirements and guidance for use. https://docs.cntd.ru/document/1200096140

Kondratieva, E.V., \& Pogrebnjak, A.D. (2014). Integrity strategies, business processes and organizational structure of the enterprise in the implementation of the energy management system. Modern problems of science and education, (2), 441. https://www.scienceeducation.ru/ru/article/view?id=12673 (in Russian).
Lesourd, J.-B., \& Ruiz, J.-M. (1984). Human Resources for Energy Management: The case of French Industry. Engineering Management International, 2(3), 195-198. https://doi.org/10.1016/0167-5419(84)90024-3 Li, H., Zhao, X., Yu, Y., Wu, T., \& Qi, Y. (2016). China's numerical management system for reducing national energy intensity. Energy Policy, 94, 64-76. https://doi.org/10.1016/j.enpol.2016.03.037

Lin, C.Y., \& Syrgabayeva, D. (2016). Mechanism of environmental concern on intention to pay more for renewable energy: Application to a developing country. Asia Pacific Management Review, 21(3), 125-134. https://doi.org/10.1016/j.apmrv.2016.01.001

Liu, X., Niu, D., Bao, C., Suk, S., \& Shishime, T. (2012). A survey study of energy saving activities of industrial companies in Taicang, China. Journal of Cleaner Production, 26, 79-89. https://doi.org/10.1016/j.jclepro.2011.12.030 Nasledov, A.D. (2013). SPSS Statistics 20 and AMOS: professional statistical analysis of data. Russia, Saint Petersburg: Peter. https://www.ozon.ru/context/detail/id/1941568/ (in Russian).

Okorokov, V.R., Volkov, I.O., \& Okorokov, R.V. (2010). Intelligent energy systems: technical capability and efficiency. Part 1. Technological and socio-economic grounds for the creation of intelligent energy systems. Energy Academy, (2), 56-64. https://elibrary.ru/download/elibrary_21827572 _16331918.pdf (in Russian).

Schulze, M., Nehler, H., Ottosson, M., \& Thollander, P. (2016). Energy management in industry - a systematic review of previous findings and an integrative conceptual framework. Journal of Cleaner Production, 112(5), 3692-3708. https://doi.org/10.1016/j.jclepro.2015.06.060 Teixeira, M.R., Mendes, P., Murt,a, E., \& Nunes, L.M. (2016). Performance indicators matrix as a methodology for energy management in municipal water services. Journal of Cleaner Production, 125, 108-120. https://doi.org/10.1016/j.jclepro.2016.03.016 Ulubeyli, S. (2013). Drivers of Environmental Performance of Cement Plants. Industrial Management \& Data Systems, 113(8), 12221244. https://doi.org/10.1108/IMDS-01-20130007

Vikhorev, K., Greenough, R., \& Brown, N. (2012). An advanced energy management framework to promote energy awareness. Journal of Cleaner Production, 43, 103-112. https://doi.org/10.1016/j.jclepro.2012.12.012 